\title{
Karakter Edible film Ulva lactuca-Kitosan sebagai Pengemas Bumbu Mi Instan
}

\author{
Sperisa Distantina a,1,*, Nuril Nasdhofa Ayuni ${ }^{\text {b,2 }}$, Vivin Sulistyaningrum Yudha Sarjani ${ }^{\text {b,3 }}$ \\ ${ }^{\text {a,b }}$ Program Ptudi Teknik Kimia Fakultas Teknik Universitas Sebelas Maret, Jl. Ir. Sutami No. 36 A, Kentingan, Surakarta 57126 \\ ${ }^{1}$ sperisa_distantina@staff.uns.ac.id
}

\section{ARTICLE INFO}

Article history

Received April 26, 2018

Revised July 11, 2018

Accepted August 08, 2018

Keywords

Ulva lactuca

Edible film

Chitosan

Noodle

\begin{abstract}
In this research, the edible films based on Ulva lactuca flour, chitosan, corn starch, and glycerol were prepared. The edible films were for wrapping of instant noodle seasoning. The aim of this research was to investigate the effect of the weight ratio of Ulva lactuca flour-chitosan on the properties of the prepared edible films. Initially, the mixture of Ulva lactuca flour, corn starch, and chitosan was stirred in acetic acid solution 1\%. After the chitosan was dissolved, the glycerol was added. The mixture was heated at $80{ }^{\circ} \mathrm{C}$ and stirred for 30 minutes. The obtained edible film solution was then poured into the anti-sticky surface and dried at oven until a constant weight was attained. The dried films were characterized, including moisture content, E. coli resistivity, hydration index, thickness, and solubility in hot water. Based on experimental data, it was found that the best composition of the edible film was $2 \mathrm{~g}$ Ulva lactuca flour, $2 \mathrm{~g}$ Chitosan, $2 \mathrm{~g}$ corn starch, $100 \mathrm{ml}$ acetic acid $1 \%$, and $1 \mathrm{~mL}$ glycerol.
\end{abstract}

This is an open access article under the CC-BY-SA license.

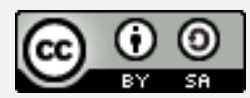

\section{Pendahuluan}

Pengemas merupakan bahan yang sangat diperlukan untuk mempertahankan kualitas suatu bahan pangan agar tetap baik. Penggunaan polimer sintetik seperti plastik banyak digunakan dalam kehidupan masyarakat terutama dalam mengemas makanan. Akan tetapi, penggunaan polimer sintetik tersebut dapat memberikan dampak negatif terhadap lingkungan, selain itu plastik dapat mencemari bahan pangan yang dikemas karena adanya zat-zat tertentu yang berpotensi karsinogen yang dapat berpindah ke dalam bahan pangan yang dikemas. Contohnya yaitu bungkus mi instan. Salah satu alternatif yang bisa dipilih yaitu membuat pengemas yang ramah lingkungan (biodegradable) sekaligus dapat dimakan yaitu edible film berbasis polimer alam. Sumber polimer alam yang ada di Indonesia untuk dijadikan edible film sangat melimpah, seperti pati jagung [1], karagenan [2], pati buah lindur [3], pati umbi kimpul [4], dan pati sukun-kitosan [5].

Di dalam penelitian ini menggunakan bahan yang cocok untuk dijadikan edible film yaitu rumput laut, kitosan dan pati jagung. Rumput laut di Indonesia mempunyai berbagai macam jenis dan salah satunya yaitu Ulva lactuca yang banyak ditemukan di pesisir selatan Laut Jawa. Ulva lactuca saat ini hanya dimanfaatkan sebagai keripik rumput laut sementara keberadaannya sangat mudah dijumpai di pantai dan perairan dangkal bahkan air payau. Ulva lactuca mengandung melatonin yang merupakan salah satu hormon antioksidan kuat yang mampu mengatasi radikal bebas [6]. Ulva yang dikeringkan mengandung 50,4\% serat, 19,6\% mineral, 8,5\% mineral, 7,9\% lemak, dan $13,6 \%$ air. Adapun vitamin dan mineral yang ada di dalam Ulva antara lain vitamin A, vitamin B1, vitamin C, dan antioksidan. 
Kitosan merupakan produk turunan dari polimer kitin yaitu produk samping (limbah) dari pengolahan industri perikanan, seperti kulit udang. Limbah kulit udang ini juga belum banyak dimanfaatkan. Kitosan tidak hanya dimanfaatkan untuk pembentukan film tetapi dapat digunakan juga sebagai antimikroba. Aktivitas antimikrobial ini sangat berpotensi apabila dimanfaatkan untuk membuat keadaan yang aseptik, misalnya pada penyembuhan luka serta penggunaan sebagai anti mikroba dalam edible film. Dalam pembuatan edible film ini sendiri, pati jagung digunakan karena memiliki karakteristik fisik yang mirip dengan plastik dan berperan sebagai filler. Untuk meningkatkan kelenturan edible film dapat ditambahkan dengan plasticizer. Plasticizer yang umumnya digunakan adalah gliserol. Tujuan penelitian ini adalah mempelajari karakter edible film berbasis karagenan-pati jagung-kitosan dan gliserol sebagai pengemas bumbu mi instan dan mengetahui pengaruh rasio berat tepung Ulva lactuca dan kitosan terhadap karakteristik edible film.

\section{Metodologi}

Bahan penelitian yang digunakan adalah rumput laut Ulva lactuca yang diperoleh dari pantai Kukup Yogyakarta. Kitosan dibeli dari toko kimia Bratachem dengan kadar air, kadar abu, dan berat molekul berturut-turut 7,5\%; 0,11\%; 24,3894 x $10^{3}-63,1553 \times 10^{5} \mathrm{~g} \mathrm{~mol}^{-1}$, pati jagung dibeli dari pasar lokal Surakarta, asam asetat $25 \%$ dibeli dari pasar lokal, dan gliserol dibeli dari Bratachem dengan $\mathrm{pH} 5,5-7,5$ dan bobot jenis $1.255-1.260 \mathrm{~g} / \mathrm{ml}$.

\subsection{Pembuatan Tepung Rumput Laut}

Ulva lactuca diperoleh dalam keadaan basah yang kemudian dicuci dengan air mengalir dan dikeringkan di bawah sinar matahari. Setelah kering rumput laut dipotong $\pm 1 \mathrm{~cm}$ kemudian dihaluskan menggunakan blender. Tepung yang lolos ayakan 80 mesh digunakan sebagai bahan baku pembuatan edible film.

\subsection{Pembuatan Edible film}

Larutan edible film dibuat dengan mencampur 6 gram tepung, $100 \mathrm{~mL}$ larutan asam asetat 1\%, dan $1 \mathrm{~mL}$ gliserol. Komposisi larutan disajikan dalam Tabel 1. Campuran tepung dan larutan asam asetat dipanaskan pada suhu $80{ }^{\circ} \mathrm{C}$ selama 30 menit. Setelah itu, gliserol ditambahkan dan diaduk selama 1 jam agar larutan homogen. Selama proses pemanasan, volume larutan dijaga tetap dengan menambah air panas. Larutan edible film $50 \mathrm{~mL}$ dituang di atas cetakan anti lengket berdiameter 24 $\mathrm{cm}$. Kemudian edible film dikeringkan dalam oven selama semalam dengan suhu $60{ }^{\circ} \mathrm{C}$. Edible film yang sudah kering dilepas dari cetakan anti lengket dan disimpan untuk proses selanjutnya.

Tabel 1. Variasi Komposisi Larutan Edible film

\begin{tabular}{lccc}
\hline \multicolumn{1}{c}{ Bahan } & Sampel 1 & Sampel 2 & Sampel 3 \\
\hline Tepung Ulva lactuca & 3 gram & 2 gram & 1 gram \\
Kitosan & 1 gram & 2 gram & 3 gram \\
Pati Jagung & 2 gram & 2 gram & 2 gram \\
Gliserol & $1 \mathrm{ml}$ & $1 \mathrm{ml}$ & $1 \mathrm{ml}$ \\
Larutan asam asetat $1 \%$ & $100 \mathrm{ml}$ & $100 \mathrm{ml}$ & $100 \mathrm{ml}$ \\
\hline
\end{tabular}

\section{Analisa}

\subsection{Analisa Kadar Air}

Kadar air (X) dalam edible film ditentukan dengan metoda pengeringan (gravimetrik). Pengujian dilakukan dengan mengoven sampel dengan berat awal Mo (gram) pada suhu $110^{\circ} \mathrm{C}$ hingga tercapai berat sampel yang konstan Mt (gram). Kadar air dievaluasi menggunakan persamaan (1).

$$
\mathrm{X}=((\mathrm{Mo}-\mathrm{Mt})) / \mathrm{Mo}
$$

\subsection{Analisa Ketebalan}

Analisa ketebalan pada edible film diukur menggunakan jangka sorong, dengan cara menempatkan edible film di antara rahang jangka sorong pada 5 tempat yang berbeda kemudian menentukan hasil ketebalan film rerata. 


\subsection{Pengujian Daya Hambat}

Analisis daya hambat bakteri menggunakan metode difusi bertujuan untuk mengetahui besar daya hambat yang dihasilkan oleh edible film dengan penambahan potongan edible film terhadap bakteri E.coli. Potongan edible film dengan diameter $6 \mathrm{~mm}$ sebanyak 5 buah diletakkan pada sebuah plat Eosin Methylen Blue Agar (EMBA) yang telah diinokulusi biakan bakteri. Plat kemudian diinkubasi pada suhu $37{ }^{\circ} \mathrm{C}$ selama 24 jam. Kriteria kekuatan daya hambat antibakteri menggunakan metode Davis and Stout [7].

\subsection{Analisa Kelembaban Bumbu dalam Edible film}

Untuk menganalisis sifat kelembaban, edible film yang telah diisi bumbu mi instan direkatkan menggunakan sealer, kemudian dibiarkan di udara terbuka. Banyaknya air dari udara yang terserap dalam edible film digunakan sebagai parameter kelembaban yang dinyatakan dengan indek hidrasi. Perhitungan indeks hidrasi menggunakan persamaan (2), dengan Mi adalah berat awal (gram) dan Ms adalah berat setelah beberapa hari (gram).

Indeks hidrasi $=(\mathrm{Mi}-\mathrm{Ms}) / \mathrm{Mi}$

\subsection{Analisa Kelarutan Edible film}

Bumbu mi instan yang dikemas menggunakan edible film dimasukkan ke dalam air rebusan mi instan. Kelarutan edible film dievaluasi berdasarkan waktu yang dibutuhkan bumbu dapat keluar dari edible film ke dalam rebusan mi instan.

\section{Hasil dan Pembahasan}

\subsection{Hasil Pembuatan Edible film}

Pada penelitian ini, edible film yang dihasilkan dengan variasi rasio berat tepung Ulva lactuca dan kitosan menunjukkan kenampakan bentuk fisik yang cukup baik, yaitu elastis atau dapat ditekuk tanpa patah. Hasil masing-masing sampel edible film dapat dilihat pada Gambar 1. Pada percobaan pendahuluan, campuran edible film tanpa penambahan gliserol menyebabkan film yang dihasilkan sangat mudah patah. Hal ini menunjukkan gliserol dengan konsentrasi $1 \%$ (volum) sudah mampu menghasilkan edible film yang elastis. Penelitian ini tidak jauh berbeda dengan edible film yang dibuat oleh Zaidar [2]. Zaidar merekomendasikan campuran edible film-nya dengan tepung rumput laut Euchepeuma Sp sebanyak 2,7\% b/v, kitosan sebanyak 1,8\% b/v dan gliserol 1,8\% v/v.

Tepung pati jagung berfungsi merekatkan campuran polimer Ulva lactuca dan kitosan. Berdasarkan percobaan pendahuluan, tanpa penambahan pati jagung akan menghasilkan edible film yang tidak homogen dibandingkan dengan penambahan pati jagung.

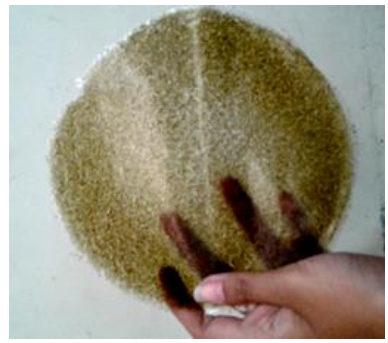

Sampel 1

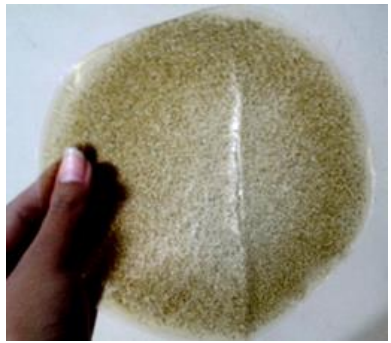

Sampel 2

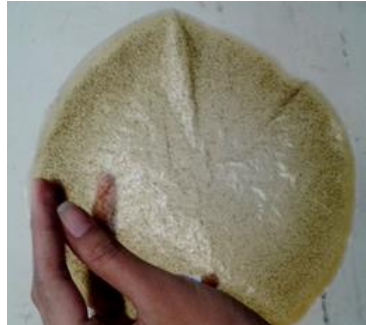

Sampel 3

Gambar 1. Edible film

\subsection{Hasil Analisa Kadar Air}

Hasil analisa kadar air pada edible film disajikan pada Tabel 2.

Tabel 2. Hasil Analisa Kadar Air pada Edible film

\begin{tabular}{ll}
\hline Sampel & Kadar Air $(\mathrm{g} / \mathrm{g})$ \\
\hline Sampel 1 & 0,019 \\
Sampel 2 & 0,024 \\
Sampel 3 & 0,025 \\
\hline
\end{tabular}


Dari Tabel 2 dapat dilihat bahwa sampel 1 mempunyai kadar air 19\%, sampel 2 sebesar 24\%, dan sampel 3 sebesar 25\%. Dengan demikian dapat disimpulkan bahwa semakin besar kandungan kitosan maka kadar air yang terkandung dalam film akan semakin besar. Hal ini kemungkinan disebabkan kadar gugus hidroksil di dalam kitosan lebih banyak dibandingkan Ulva lactuca. Kadar air yang besar dapat berpengaruh pada ketahanan bumbu dalam kemasan, dimana bumbu dapat menyerap air yang ada dalam film.

\subsection{Hasil Analisa Ketebalan}

Hasil pengukuran dari ketebalan edible film disajikan pada Tabel 3.

Tabel 3. Hasil Analisa Ketebalan Edible film

\begin{tabular}{ccccccc}
\hline Sampel & $\begin{array}{c}\text { Tebal 1 } \\
(\mathbf{m m})\end{array}$ & $\begin{array}{c}\text { Tebal 2 } \\
(\mathbf{m m})\end{array}$ & $\begin{array}{c}\text { Tebal 3 } \\
(\mathbf{m m})\end{array}$ & $\begin{array}{c}\text { Tebal 4 } \\
(\mathbf{m m})\end{array}$ & $\begin{array}{c}\text { Tebal 5 } \\
(\mathbf{m m})\end{array}$ & $\begin{array}{c}\text { Rata-rata } \\
(\mathbf{m m})\end{array}$ \\
\hline Sampel 1 & 0,002 & 0,002 & 0,0019 & 0,0023 & 0,002 & 0,00204 \\
Sampel 2 & 0,002 & 0,0019 & 0,002 & 0,0019 & 0,002 & 0,00196 \\
Sampel 3 & 0,002 & 0,0019 & 0,0018 & 0,0018 & 0,002 & 0,0019 \\
\hline
\end{tabular}

Dari Tabel 3 dapat diketahui bahwa ketebalan edible film sampel 1 sebesar 0,00204 mm, sampel 2 sebesar 0,00196 mm, dan sampel 3 sebesar 0,0019 mm. Dapat disimpulkan bahwa ketebalan edible film berkurang seiring dengan bertambahnya jumlah kandungan kitosan dibandingkan dengan kandungan tepung rumput laut. Ketebalan pengemas akan mempengaruhi umur simpan produk, yaitu semakin tebal film maka laju transmisi uap air dan gas akan semakin rendah. Akan tetapi, kenampakan edible film yang tebal akan berwarna semakin buram atau tidak transparan.

\subsection{Hasil Pengujian Daya Hambat Bakteri}

Hasil pengujian efektivitas zat antibakteri yang telah dilakukan dapat dilihat pada Gambar 2 dan Tabel 4. Berdasarkan Tabel 4 dapat diketahui bahwa sampel 1 mempunyai daya hambat lemah, sedangkan sampel 2 dan 3 mempunyai daya hambat sedang. Sehingga dari hasil pengujian dapat disimpulkan bahwa edible film dengan penambahan kitosan pada sampel 3 memiliki efektivitas zat antibakteri yang kuat dengan diameter zona hambat sebesar 6,168 $\mathrm{mm}$ dan luas zona bening sebesar $29,864 \mathrm{~mm}^{2}$.

Tabel 4. Hasil Perhitungan Zona Hambat Metode Difusi

\begin{tabular}{ccccc}
\hline No. & Sampel & $\begin{array}{c}\text { Diameter zona } \\
\text { hambat }(\mathbf{m m})\end{array}$ & $\begin{array}{c}\text { Luas zona hambat } \\
\left(\mathbf{m m}^{\mathbf{2}}\right)\end{array}$ & $\begin{array}{c}\text { Daya } \\
\text { hambat }\end{array}$ \\
\hline 1 & Sampel 1 & 4,376 & 15,032 & Lemah \\
2 & Sampel 2 & 5,284 & 21,920 & Sedang \\
3 & Sampel 3 & 6,168 & 29,864 & Sedang \\
\hline
\end{tabular}

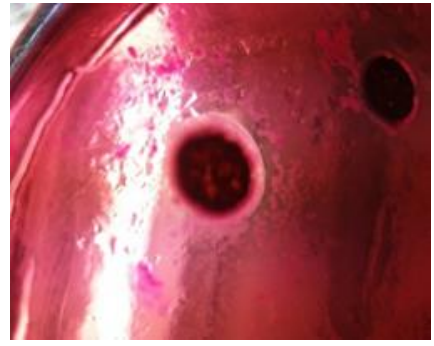

Sampel 1

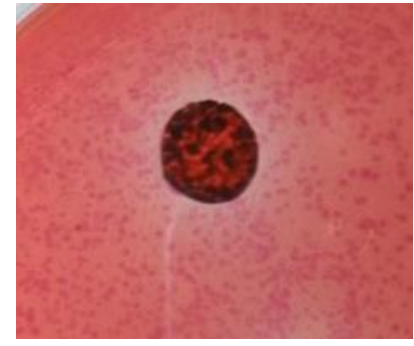

Sampel 2

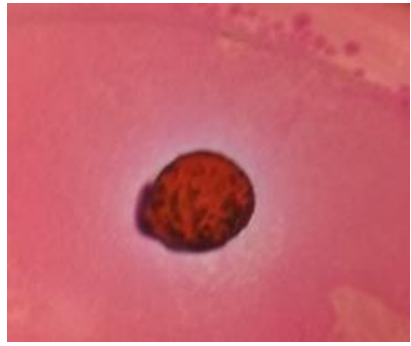

Sampel 3

Gambar 2. Hasil Analisa Daya Hambat Bakteri pada Masing-Masing Sampel

\subsection{Hasil Analisis Kelembaban Bumbu dalam Edible film}

Gambar 3 menunjukkan edible film yang sudah diaplikasikan sebagai pengemas bumbu. Hasil analisis kelembaban bumbu dalam edible film dapat dilihat pada Tabel 5. 


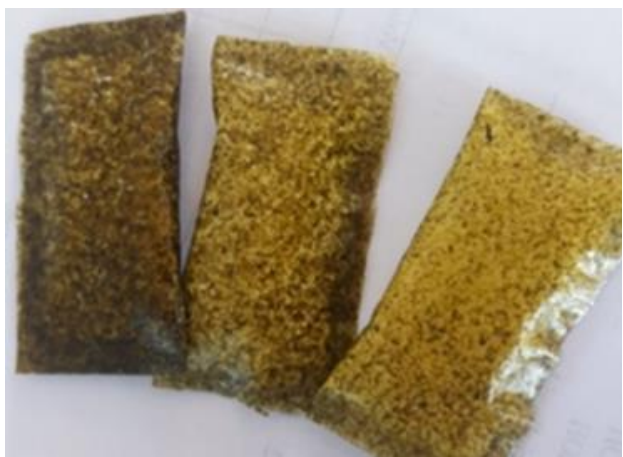

Gambar 3. Edible film Sebagai Pengemas Bumbu

Tabel 5. Hasil Analisa Kelembaban Bumbu dalam Edible film

\begin{tabular}{|c|c|c|c|c|}
\hline Hari ke- & $\begin{array}{l}\text { Indeks Hidrasi } \\
\text { Sampel } 1\end{array}$ & $\begin{array}{l}\text { Indeks Hidrasi } \\
\text { Sampel } 2\end{array}$ & $\begin{array}{l}\text { Indeks Hidrasi } \\
\text { Sampel } 3\end{array}$ & Keterangan \\
\hline 1 & 0 & 0 & 0 & $\begin{array}{l}\text { Pada sampel } 1,2 \text { dan } 3 \text { bumbu dalam } \\
\text { edible film dalam keadaan baik. }\end{array}$ \\
\hline 2 & 0,041 & 0,045 & 0,040 & $\begin{array}{l}\text { Pada sampel } 1,2 \text { dan } 3 \text { bumbu dalam } \\
\text { edible film dalam keadaan baik. }\end{array}$ \\
\hline 3 & 0,051 & 0,062 & 0,062 & $\begin{array}{l}\text { Pada sampel } 1,2 \text { dan } 3 \text { bumbu dalam } \\
\text { edible film dalam keadaan baik. }\end{array}$ \\
\hline 4 & 0,068 & 0,070 & 0,066 & $\begin{array}{l}\text { Pada sampel } 1 \text { dan } 2 \text { bumbu dalam } \\
\text { keadaan baik. Pada sampel } 3 \text { bumbu } \\
\text { dalam edible film mulai lengket. }\end{array}$ \\
\hline 5 & 0,096 & 0,081 & 0,101 & $\begin{array}{l}\text { Pada sampel } 1 \text { dan } 2 \text { bumbu dalam edible } \\
\text { film mulai lengket. Pada sampel } 3 \text { bumbu } \\
\text { di dalam edible film lengket. }\end{array}$ \\
\hline 6 & 0,111 & 0,107 & - & $\begin{array}{l}\text { Pada sampel } 1,2 \text {, dan } 3 \text { bumbu dalam } \\
\text { edible lengket. }\end{array}$ \\
\hline
\end{tabular}

Dari Tabel 5 dapat diketahui bahwa sampel menunjukan penurunan kualitas fisik ketika indeks hidrasi mencapai 0,1. Sampel 3 bertahan hingga hari ke-5 dengan indeks hidrasi terakhir sebesar 0,101, sampel 2 dan sampel 1 dapat bertahan hingga hari ke 6 dengan indeks hidrasi sebesar 0,107, dan 0,111. Dengan demikian, dapat dikatakan bahwa sampel 2 dengan komposisi 2 gram $/ 6$ gram Ulva lactuca, 2 gram/ 6 gram kitosan, 2 gram/ 6 gram pati jagung, dan $1 \mathrm{ml} / 6$ gram gliserol memiliki ketahanan hidrasi paling baik untuk dijadikan sebagai pengemas bumbu mi instan.

\subsection{Hasil Analisis Kelarutan Edible film}

Dalam pengaplikasian edible film sebagai pengemas bumbu mi instan dapat dilihat bahwa edible film tidak mempengaruhi rasa, warna maupun bau pada mi instan. Edible film tidak larut bersama bumbu mi instan, melainkan sobek dan memiliki tekstur seperti sayuran rebus. Bumbu mi instan dapat keluar dari film dan larut di dalam air rebusan mi instan selama \pm 1 menit. Ketahanan bumbu yang dikemas dalam edible film yang dihasilkan dalam riset ini belum dibandingkan dengan ketahanan bumbu yang dikemas seperti kemasan mi komersial.

\section{Kesimpulan}

Hasil penelitian menunjukkan bahwa edible film dari Ulva lactuca dan kitosan mampu efektif menghambat bakteri dan memiliki sifat karakteristik edible film yang baik. Komposisi terbaik pada penelitian ini adalah tepung Ulva lactuca sebesar 2 gram, tepung kitosan 2, pati jagung 2, gliserol 1 $\mathrm{ml}$, dan larutan asam asetat $1 \% 100 \mathrm{ml}$. Edible film ini memiliki ketebalan 0,00196 mm, kadar air $24 \%$, indeks hidrasi sebesar $0,107 \mathrm{~g} \mathrm{H}_{2} \mathrm{O} / \mathrm{g}$ film, dan diameter daya hambat bakteri sebesar 5,284 $\mathrm{mm}$. Edible film yang dihasilkan berpotensi sebagai pengemas bumbu mi instan. 


\section{Ucapan Terimakasih}

Tim peneliti menyampaikan terima kasih kepada Program Studi Diploma 3 Teknik Kimia Fakultas Teknik Universitas Sebelas Maret, Surakarta yang telah memberikan sarana dan prasarana sehingga penelitian ini dapat dilaksanakan. Terima kasih juga kami sampaikan kepada Universitas Sebelas Maret yang telah mendanai sebagian kegiatan ini melalui Skim Penelitian Hibah Fundamental PNBP UNS 2016.

\section{Daftar Notasi}

$\mathrm{X}=$ kadar air, $\mathrm{g}$ air/g bahan

$\mathrm{M}=$ massa, $\mathrm{g}$

\section{Daftar Pustaka}

[1] Kusumawati, D.H. dan Putri W.D.R.P. 2013. Karakteristik fisik dan kimia edible film pati jagung yang diinkorporasi dengan perasan temu hitam. Jurnal Pangan dan Agroindustri, 1: 90-100

[2] Zaidar E., Bulan, R., Alvian, Z., Sri, T.R.S., dan Dwi L.A. 2013. Pembuatan Edible film Dari Campuran Tepung Rumput Laut (Euchepeuma Sp.) dengan Gliserol Dan Kitosan.2013. Prosiding Semirata FMIPA Universitas Lampung, 125-130.

[3] Jacoeb, A.M., Nugraha, R., dan Utari, S. P. S. D. 2014. Pembuatan edible film dari pati buah Lindur dengan penambahan gliserol dan karaginan. JPHPI. 17(1): 14-21.

[4] Warkoyo, Eahardjo, B., Marseno, D. W., dan Karyadi, J.N.W. 2014. Sifat fisik, mekanik dan barrier edible film berbasis pati umbi kimpul (Xanthosoma sagittifolium) yang diinkorporasi dengan kalium sorbat. Agritech. 34(1): 72-81.

[5] Setiani, W., Sudiarti, T. dan Rahmidar, L. 2013. Preparasi dan karakterisasi edible film dari poliblend pati sukun-kitosan. Valensi, 3(2): 100-109.

[6] Widyaningsih, W., Sativa, R., dan Primardiana, I. 2015. Efek antioksidan ekstrak Etanol Ganggang Hijau (Ulva lactuca L.) terhadap kadar malondialdehid (MDA) dan aktivitas Enzim Superoksida Dismutase (SOD) hepar tikus yang diinduksi CCl4. Media Farmasi. 12(2): 163-175.

[7] Davis, W.W. and Stout, T.R. 1971. Disc plate method of microbiological antibiotic assay. Applied Microbiology. 22(4): 666-670. 